\title{
Targeting the mitochondrial apoptotic pathway: a preferred approach in hematologic malignancies?
}

\author{
K Brinkmann ${ }^{1,2}$ and H Kashkar, ${ }^{*, 1,2}$
}

Acquired resistance toward apoptosis represents one of the hallmarks of human cancer and a major cause of the inefficacy of most anticancer treatment regimens. Based on its ability to inhibit apoptosis, the B-cell lymphoma/leukemia 2 (Bcl-2) protein family has garnered the most attention as a promising therapeutic target in cancer. Accordingly, efforts have lately been focused on the development of drugs targeting Bcl-2 proteins with considerable therapeutic success, particularly in hematologic malignancies. Here, we review the previous studies and highlight the pivotal role of the $\mathrm{Bcl}-2$ protein family in the homeostasis of hematologic tissue compartment. This knowledge provides more insight into why some cancers are more sensitive to Bcl-2 targeting than others and will foster the clinical evaluation of Bcl-2-targeting strategies in cancer by avoiding severe on-target side effects in the development of healthy tissues.

Cell Death and Disease (2014) 5, e1098; doi:10.1038/cddis.2014.61; published online 6 March 2014

Subject Category: Cancer

Facts

- Inefficient mitochondrial apoptosis is a key determinant in therapeutic success of a number of anticancer regimens.

- Mitochondrial apoptosis is tightly controlled by the $\mathrm{Bcl}-2$ protein family.

- Bcl-2 proteins have a crucial role in the development and the homeostasis of cells of hematopoietic origin.

- Imbalanced expression of Bcl-2-family members has been readily associated with the development of hematologic malignancies such as lymphoma, leukemia or myeloma.

- Several small-molecule inhibitors of Bcl-2 proteins have been developed and are currently under clinical evaluation with a marked susceptibility to hematologic malignancies.

\section{Open Questions}

- What is the impact of Bcl-2-targeting anticancer therapy in solid tumors?

- How can hematologic side effects be avoided upon Bcl-2targeting anticancer therapy?

- How and in combination with which additional chemotherapeutics provoke $\mathrm{Bcl}-2$-antagonizing protocols for a potent anticancer effect?
Compelling studies conducted over the last 20 years established the concept that apoptosis serves as a natural barrier to cancer development, which is triggered autonomously during the process of malignant transformation or as a result of anticancer treatment. ${ }^{1}$ Accordingly, acquired resistance toward apoptosis is a hallmark of most types of human cancer and a major cause of the inefficacy of most anticancer treatment regimens. ${ }^{2}$ Mitochondria represents a central regulatory node in the apoptotic machinery and the decisive event thereby is the process of mitochondrial outer membrane permeabilization (MOMP). Upon MOMP, multiple pro-apoptotic molecules are released from the mitochondrial intermembrane space to coordinate most of the hallmarks of apoptosis, like nuclear condensation and caspase activation. Inefficient MOMP has been considered to be one of the key determinants of therapeutic success of a number of anticancer regimens. Accordingly, reactivation of the mitochondrial apoptotic machinery by restoration of MOMP has been viewed as a promising strategy to combat human cancer. ${ }^{1}$

\section{Bcl-2 Protein Family, the Gatekeepers of Mitochondrial Outer Membrane}

MOMP is tightly controlled by the Bcl-2 (B-cell lymphoma/ leukemia 2) protein family via protein-protein interaction (Figure 1). Bcl-2-family members have been grouped into

\footnotetext{
${ }^{1}$ Centre for Molecular Medicine Cologne (CMMC), Cologne Excellence Cluster on Cellular Stress Responses in Aging-Associated Diseases (CECAD), Köln, Germany and ${ }^{2}$ Institute for Medical Microbiology, Immunology and Hygiene (IMMIH), University of Cologne, Köln, Germany

${ }^{*}$ Corresponding author: H Kashkar, Institute for Medical Microbiology, Immunology and Hygiene (IMMIH), University of Cologne, Goldenfelsstrasse 19-21, Köln D-50935, Germany. Tel: +49 221478 7285; Fax: +49 221478 7288; E-mail: h.kashkar@uni-koeln.de

Keywords: apoptosis; $\mathrm{BH} 3$ mimetics; $\mathrm{Bcl}-2$ targeting

Abbreviations: AML, acute myeloid leukemia; ALL, acute lymphoblastic leukemia; BL, Burkitt's lymphoma; CGH, comparative genomic hybridization; CLL, chronic lymphocytic leukemia; CML, chronic myeloid leukemia; CR, complete remission; DLBL, diffuse large B-cell lymphoma; FDA, Food and Drug Administration; HL, Hodgkin's lymphoma; HSC, hematopoietic stem cells; IMS, mitochondrial intermembrane space; MCL, mantle cell lymphoma; MM, multiple myeloma; MOMP, mitochondrial outer membrane permeabilization; PR, partial remission; SCLC, small cell lung cancer; SD, stable disease; SLE, systemic lupus erythematosus Received 06.12.13; revised 23.1.14; accepted 24.1.14; Edited by H-U Simon
} 


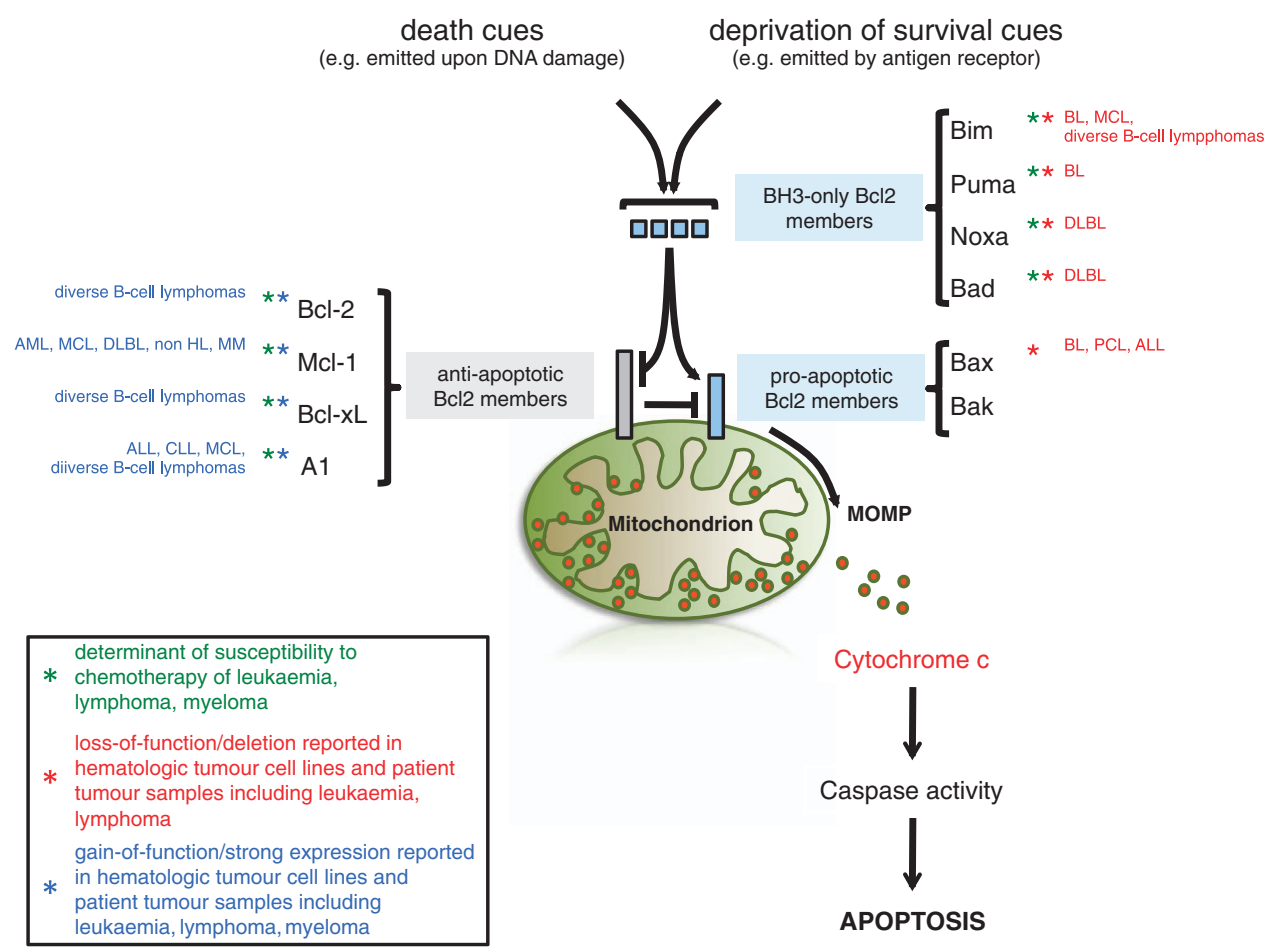

Figure $1 \mathrm{Bcl}-2$ protein family in apoptosis and hematologic malignancies. Mitochondria represent a cellular regulatory node in apoptosis induced by death cues (e.g. DNA damage) or by the deprivation of survival signals (e.g. emitted by antigen receptor). The pro-apoptotic activity of mitochondria involves the mitochondrial outer membrane permeabilization (MOMP), which is tightly regulated by anti- and pro-apoptotic Bcl-2 protein family members. This is in turn is controlled by BH3-only proteins that initiate MOMP by either direct binding to the pro-apoptotic Bcl-2 members or by antagonizing their anti-apoptotic counterparts. Upon MOMP cytochrome $c$ is released from the mitochondrial intermembrane space and initiates proteolytic activation of caspases, culminating in apoptotic cell death. Imbalanced expression of Bcl-2-family members has been readily associated with the development of hematologic malignancies such as lymphoma, leukemia or myeloma as summarized. PCL, plasma cell leukemia. Astrisks indicate the association of the Bcl-2 protein family members (gain- or loss-of-function) in chemosusceptibility (green) and/or malignant transformation of lymphoid malignancies (red or blue)

three classes (Figure 1) The antiapoptotic Bcl-2-family members including Bcl-2, Bcl-xl and Mcl-1 inhibit apoptosis, whereas a second class including Bax and Bak promotes apoptosis. A third divergent class of $\mathrm{BH} 3-$ only proteins including Bad, Bik, Bid, Bim, Bmf, Noxa and Puma have a conserved $\mathrm{BH} 3$ domain that can bind and regulate the activity of $\mathrm{Bcl}-2$ proteins. Recent evidence suggests that $\mathrm{BH} 3-$ only proteins derepress and liberate Bax and Bak by direct binding and inhibition of anti-apoptotic family members including Bcl-2. By contrast, an opposing model postulates direct activation of Bax and Bak by $\mathrm{BH} 3-o n l y$ proteins including Bim, tBid and Puma (Figure 1). ${ }^{1}$

\section{Apoptosis Represents a Fundamental Regulatory System During Hematopoiesis}

Hematopoiesis gives rise to blood cells of different lineages throughout normal life. Abnormalities in this developmental program lead to blood cell diseases including leukemia and lymphoma. ${ }^{3}$ During hematopoiesis, a complex interacting network of cytokines and adhesion molecules tightly regulates the survival of progenitor cells, both positively and negatively. Following deprivation of these survival cues apoptotic death of progenitor cells actively safeguards hematologic homeostasis and prevents malignant transformation. ${ }^{4}$ Accordingly, almost $90 \%$ of pre-T- and B-cells undergo apoptosis during maturation in the thymus or bone marrow, respectively. Furthermore, after antigen exposure T- and B-cells undergo clonal expansion, giving rise to the generation of a large number of active effector lymphocytes. Apoptosis triggers the shutdown of the immune response when an infection has been overcome. ${ }^{5}$ Importantly, key elements of the basic apoptotic signaling machinery have been first discovered in the hematopoietic system associated with diseases when aberrantly expressed (Bcl-2 and lymphoma) or mutated (CD95 and ALPS), ${ }^{6}$ underscoring the intimate association of the apoptotic machinery, in particular, Bcl-2 proteins with the homeostasis of the hematopoietic system (Figure 1).

\section{Bcl-2 Proteins - Their Physiologic Role in Cells of Hematopoietic System and Hematologic Cancer}

Imbalanced expression of Bcl-2-family members has been readily associated with the development of hematologic malignancies such as human lymphoma, leukemia or myeloma. Besides the extensive biochemical characterization, gene-targeting experiments in mice repeatedly showed that $\mathrm{Bcl}-2$ proteins are essential for the development and homeostasis of the hematopoietic system. In the following we will summarize the data obtained in the previous years demonstrating the pivotal role of $\mathrm{Bcl}-2$ proteins in hematologic compartment homeostasis (Figure 2), which may account for 


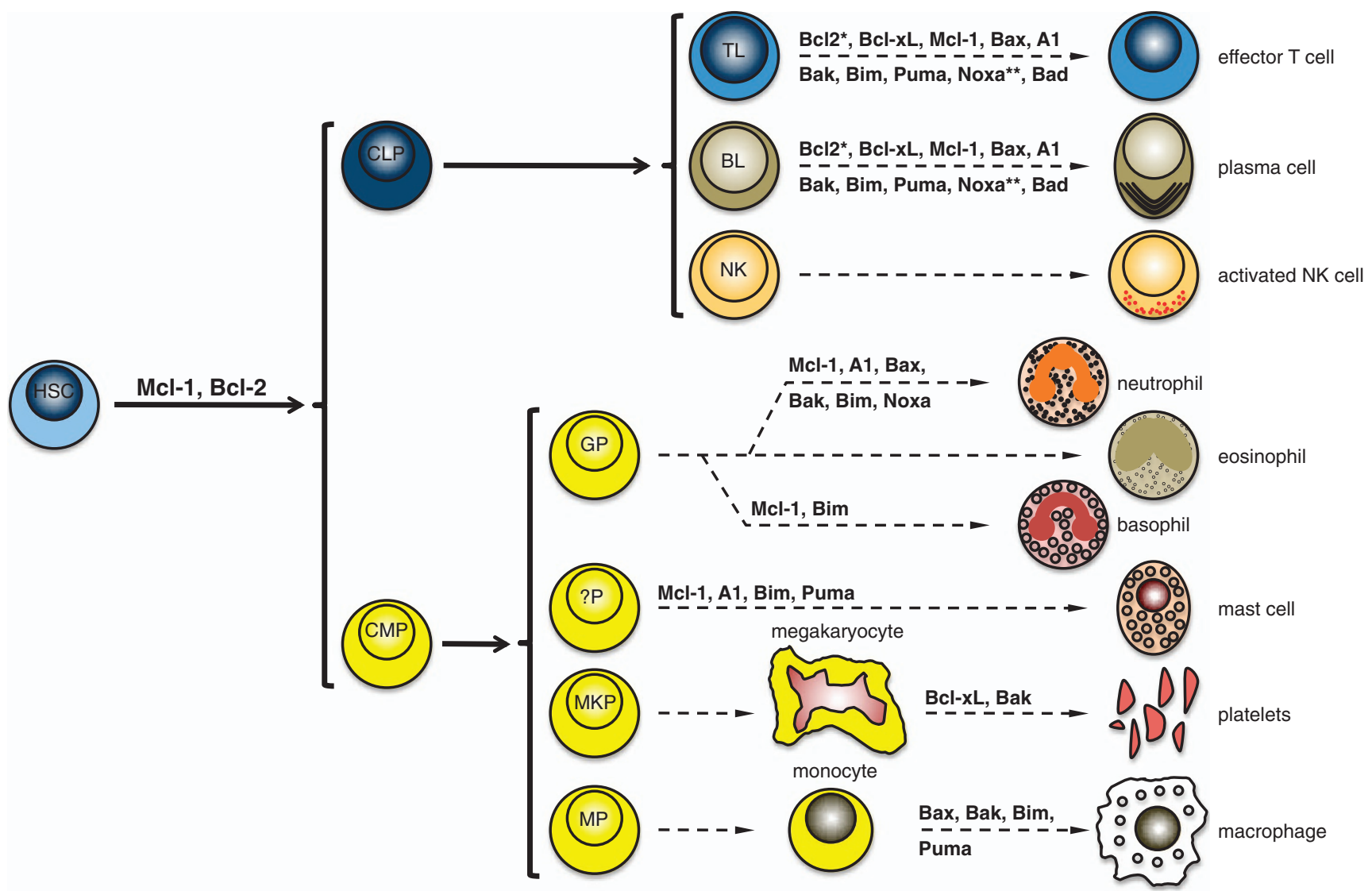

Figure 2 The $\mathrm{Bcl}-2$ protein family in the development and homeostasis of the hematologic system. A summary of the current knowledge about the physiological role of Bcl-2 protein family in hematopoiesis based on the results obtained in mice. common lymphoid progenitor (CLP), common myeloid progenitor (CMP), T lymphocyte (TL), BL (B lymphocyte), NK (natural killer cells), GP (granulocyte progenitor), ?P (unknown progenitor), MKP (megakaryocyte progenitor), MP (monocyte progenitor). *Bcl-2 ablation reduces the number and the lifespan of leukocytes but presumably does not impact on lymphoid development. ${ }^{* *}$ Noxa impacts on the lymphocyte function upon infection but is not involved in lymphoid development

the observed association of hematologic malignancies with imbalanced Bcl-2 expression (Figure 1) and the marked susceptibility of hematologic malignancies toward Bcl-2targeting strategies (Figure 3 and Table 1).

\section{Antiapoptotic Bcl-2 Proteins}

The discovery of Bcl-2 family of proteins is intimately linked to many B-cell malignancies.

The $b c l-2$ gene was initially discovered at the $t(14 ; 18)$ chromosome translocation breakpoint in B-cell follicular lymphomas, where its transcription becomes excessively driven by the immunoglobulin heavy chain gene promoter and enhancer on chromosome $14 .^{7}$ In line with the data obtained in human tumor samples, mice lacking $b c l-2$ have severe defects in the development of lymphoid progenitor cells from hematopoietic stem cells (HSC) and display reduced lifespan of lymphoid and myeloid cells. ${ }^{8-10}$ Conversely, early studies reported that Bcl-2 overexpression enhanced the survival of $\mathrm{T}^{-11}$ and B-cells. ${ }^{12}$ More strikingly, ectopic expression of $\mathrm{Bcl}-2$ was capable of rescuing lymphopoiesis in SCID mice. ${ }^{13}$ The oncogenic potential of $\mathrm{Bcl}-2$ was explored by showing that its overexpression facilitates the $c$-myc-driven proliferation of B-cell precursors and tumorigenesis. ${ }^{14}$

Myeloid cell leukemia sequence 1 (Mcl-1) was identified as an immediate-early gene induced by TPA-mediated differentiation of a human myeloid leukemia cell line $(\mathrm{ML}-1){ }^{15} \mathrm{mcl}-1$ is one of the most highly amplified genes in a variety of human cancers. Specifically, elevated Mcl-1 was shown in acute myeloid leukaemia (AML), ${ }^{16}$ mantle cell lymphoma (MCL), ${ }^{17}$ diffuse large B-cell lymphoma (DLBL), ${ }^{18}$ non-Hodgkin's lymphoma ${ }^{19}$ and multiple myeloma (MM). ${ }^{20}$ In line with these observations, removal of Mcl-1 caused cell death of transformed $\mathrm{AML}$ and rescued $\mathrm{AML}$-afflicted mice from disease development. ${ }^{21} \mathrm{Mcl}-1$ is unique among the antiapoptotic $\mathrm{Bcl}-2$ members in being essential for early embryonic development. Deletion of $\mathrm{mcl}-1$ results in lethality at embryonic day $3.5,{ }^{22}$ whereas tissue-specific ablation of mcl-1 in mice demonstrated that $\mathrm{Mcl}-1$ is essential for the survival and the development of B- and T-lymphocytes, ${ }^{23}$ germinal center formation and B-cell memory, ${ }^{24}$ plasma cells, ${ }^{25}$ neutrophils, ${ }^{26}$ basophil and mast cells, ${ }^{27}$ and has an obligate role for the survival of HSCs. ${ }^{28}$ Remarkably, inducible Cre-mediated deletion of even a single Mcl-1 allele substantially impaired the growth of $c$-myc-driven mouse 


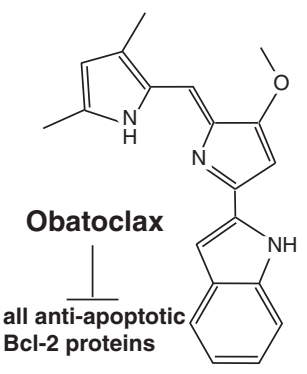

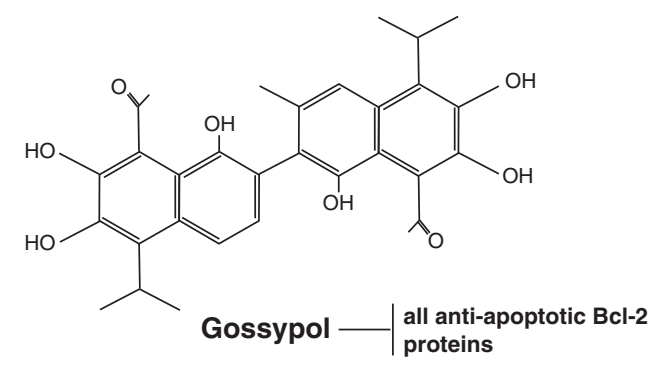<smiles></smiles><smiles>CC(C)(C)CC(Br)(Br)Br</smiles>

Figure 3 Structural view of BH3 mimetics. Obatoclax (GX15-070) is a Bcl-2 homology domain-3 (BH3) mimetic. It occupies a hydrophobic cleft within the BH3-binding groove of $\mathrm{Bcl}-2$, antagonizing $\mathrm{Bcl}-2$ and thus inducing apoptosis. Gossypol is a natural phenol derived from the cotton plant (genus: Gossypium). The phenolic aldehyde permeates cells and acts as an inhibitor for several dehydrogenase enzymes and in particular in its ( $R$ )-configuration (known as AT-101) it acts as a pan-Bcl-2-family inhibitor, capable to bind and inhibit most antiapoptotic Bcl-2-family members. Abt-737 is a small-molecule BH3 mimetic developed by Abbott that binds to the hydrophobic BH3-binding groove of antiapoptotic Bcl-2-family members. ABT-737 binds with high affinity ( $\mathrm{Ki} \leq 1 \mathrm{nM})$ to Bcl-xl, Bcl-2 and Bcl-w, but not to the less-homologous proteins Bcl-b, Mcl-1 and A1. Abt-263 (Navitoclax, Abbott Laboratories) is structurally related to Abt-737. It represents an orallybioavailable small-molecule Bad-like BH3 mimetic which efficiently antagonizes antiapoptotic Bcl-2-family members (Ki's of $<1 \mathrm{nM}$ for Bcl-2, Bcl-xl and Bcl-w). Abt-199, generated by Abbott is a high-affinity Bcl-2-selective small-molecule BH3 mimetic. It is not interacting with $\mathrm{Bcl}-\mathrm{xl}$ and thus not interfering with platelet homeostasis

lymphomas. ${ }^{29}$ In line with these observations, overexpression of $\mathrm{Mcl}-1$ results in the development of lymphomas ${ }^{30}$ identifying Mcl-1 as a critical regulator of hematopoiesis and hematologic malignancies.
Initial studies using low stringency hybridization assays in chicken lymphoid cells identified $b c l-x$, a $b c l-2$-related gene that can function as a Bcl-2-independent regulator of apoptosis. Alternative splicing results in two distinct $b c l-x$ 
Table 1 Published phase II/II clinical trials of drugs targeting the Bcl-2 family

\begin{tabular}{ll}
\hline Study description & Tumor entity \\
\hline Phase II trial of oblimersen as advanced CLL
\end{tabular}

Phase II trial of oblimersen as advanced CLL

a single treatment

Phase III trial of fludarabine plus cyclophosphamide with (group 1)

or without (group 2)

oblimersen

Phase II trial of oblimersen in combination with rituximab

Phase II trial of oblimersen in

combination with gemtuzumab

ozogamicin

Phase II trial of oblimersen in combination with dexametha-

sone and thalidomide

Phase III trial of dexametha-

sone with (group 1) or without

oblimersen (group 2)

Phase II trial oblimersen in

combination with dacarbazine kin Iymphoma

AML

Relapsed MM

Advanced MM

Advanced melanoma
Relapsed or refractory CLL

Recurrent B-cell non-Hodg-

(n)

Phase II trial of docetaxel in combination with oblimersen Phase I/II trial of gossypol in combination with topotecan Phase II trial of gossypol in combination with docetaxel Phase II trial of gossypol

Phase II trial of docetaxel plus prednisone in combination with gossypol Phase II trial of obatoclax mesylate

Phase II trial of Abt-263
Castration-resistant prostate cancer Relapsed and refractory

SCLC

NSCLC

Chemotherapy-sensitive recurrent extensive-stage SCLC

Metastatic castrationresistant prostate cancer

Myelofibrosis

Relapsed SCLC

\section{Study summary}

Reference

2/26 patients achieved $P R ; 7 / 17$ patients showed $\geq 50 \%$ reduction in splenomegaly; $2 / 7$ patients showed complete disappearance of hepatomegaly; 7/22 patients showed $\geq 50 \%$ reduction of lymphadenopathy; $11 / 22$ patients showed $\geq 50 \%$ reduction in circulating lymphocyte count

$17 \% \mathrm{CR}$ in group 1 versus $7 \% \mathrm{CR}$ in group 2 . Among patients with $\mathrm{CR}$, response duration was significantly longer in group 1 versus group 2 (>36 months versus 22 months); $40 \%$ of patients with CR or PR of group 1 showed a significant 5 -year survival benefit

CR in $23 \%$ patients, a PR in $19 \%$ patients and $28 \%$ patients Pro et al. ${ }^{101}$ showed a minimal response or stable disease

$12 / 48$ patients $(25 \%)$ achieved a major response with 5 CR Moore et al. ${ }^{102}$ and $7 \mathrm{CR}$ without platelet recovery. Ten of the 12 patients who achieved a major response survived $>6$ months compared with six of 36 nonresponders

$55 \%$ of patients achieved objective responses, including CR Badros et al. ${ }^{103}$ in $2 / 33$ patients, $4 / 33$ near CRs, PR in $12 / 33$ patients and $6 / 33$ patients had minimal responses

No significant differences between the two groups in time to Chanantumor progression or objective-response rates $\quad$ Khan et al. ${ }^{105}$

The addition of oblimersen to dacarbazine yielded a trend toward improved survival at 24-month minimum follow-up (median, 9.0 versus 7.8 months; $P=077$ ) and significant increases in progression-free survival (median, 2.6 versus 1.6 months; $P<001$ ), overall response (13.5 versus $7.5 \%$; $P=007)$, complete response (2.8 versus $0.8 \%)$, and durable response $(7.3$ versus $3.6 \% ; P=03)$

No statistical difference in overall survival

No convincing clinical activity

No convincing clinical activity

Bedikian et al. ${ }^{104}$

No observed clinical activity

No statistical difference in overall survival

Sternberg et al. ${ }^{106}$

Heist et al. ${ }^{115}$

Ready et al. ${ }^{117}$

Baggstrom et al. ${ }^{118}$

Sonpavde et al..$^{119}$

No convincing clinical activity

Parikh et al. ${ }^{132}$

PR in $2.6 \%$ and stable disease in $23 \%$ patients. The most common toxicity associated with navitoclax was thrombocytopenia, which reached grade III-IV in $41 \%$ of patients.

Abbreviations: AML, acute myeloid leukemia; CLL, chronic lymphocytic leukemia; CR, complete remission; MM, multiple myeloma; NSCLC, non-small cell lung cancer; PR, partial remission; SCLC, small cell lung cancer

mRNAs. The protein product of the larger mRNA, Bcl-xl, was similar in size and predicted structure to Bcl-2. ${ }^{31}$ Similar to $\mathrm{Bcl}-2$ and $\mathrm{Mcl}-1$, elevated $\mathrm{Bcl}-\mathrm{xl}$ expression has been frequently observed in hematologic malignancies and is implicated to have a role in disease progression. ${ }^{32} \mathrm{bcl}-\mathrm{x}^{-1-}$ mice died at embryonic day 13 and displayed massive cell death of immature hematopoietic cells and thus severe defects in the development of the hematopoietic system, ${ }^{33}$ underlining the essential role of $\mathrm{Bcl}-\mathrm{x}$ for the survival and development of lymphoid cells. In line with these observations, an independent approach showed that genetic ablation or pharmacological inactivation of $\mathrm{Bcl}-\mathrm{xl}$ reduces platelet half-life and causes thrombocytopenia in mice. ${ }^{34}$ The central role of $\mathrm{Bcl}-\mathrm{xl}$ in malignant transformation of hematopoietic cells was further strengthened with the fact that transgenic mice overexpressing Bcl-xl developed lymphomas. ${ }^{35}$
In contrast to $\mathrm{Bcl}-2$ and $\mathrm{Mcl}-1$ the described roles for $\mathrm{A} 1$ are more restricted. A1 is a hematopoietic tissue-specific gene that is expressed in several hematopoietic cell lineages, including T-helper lymphocytes, macrophages and neutrophils. ${ }^{36}$ High expression of a1 mRNA was reported in acute lymphoblastic leukemia (ALL) and chronic lymphocytic leukemia (CLL), MCL and multiple types of DLBL, ${ }^{37-39}$ especially the OxPhos subgroup of DLBL. ${ }^{40}$ Mouse a1 mRNA is induced during myeloid differentiation, ${ }^{36}$ mast cell activation upon an allergic reaction, ${ }^{41}$ lymphocyte development ${ }^{42}$ and lymphocyte and macrophage activation, ${ }^{36}$ emphasizing the importance of $\mathrm{A} 1$ in the hematopoietic system. Genetic deletions of $a 1$ in mice are challenging owing to the existence of multiple genetic copies of the 1 gene in mice with a highly cell type-specific expression pattern. However, mice lacking only one a1 gene, a1-a, show hematologic defects including 
reduced number of neutrophils ${ }^{43}$ and mast cells owing to enhanced apoptosis. ${ }^{41}$ A1 knockdown mice harboring a tg-driven short-hairpin RNA (shRNA) targeting $A 1-a, A 1-b$ and $A 1-d$ mRNA did not show a severe phenotype. However, gene silencing appeared to be highly restricted and a significant knockdown of A1 abundance could only be achieved in thymocytes, while it was not efficient in mature lymphocytes. ${ }^{44}$ Remarkably, a tg shA1 mouse expressing a micro-RNA30-based precursor harboring a shRNA able to efficiently target all $A 1$ isoforms revealed multiple roles of $\mathrm{A} 1$ in lymphocyte development. Specifically, knockdown of $A 1$ impaired early stages of T-cell differentiation, B-cell homeostasis and sensitized transitional as well as follicular B-cells to apoptosis induced by ligation of the B-cell receptor. As a consequence, B-cell proliferation in response to mitogens was severely impaired, whereas T-cell survival was not affected. Moreover, granulocytes showed increased spontaneous death in culture or failed to accumulate in significant numbers in vivo. ${ }^{45}$ Enforced expression of $\mathrm{A} 1$-a in $\mathrm{T}$-cells was found to accelerate $\mathrm{T}$-cell survival in a1-a tg mice. ${ }^{46}$ Overexpression of A1 in B- and T-cell lineages in E $\mu$-a1-a $\operatorname{tg}$ mice extended the lifespan of thymocytes and early B-cells. ${ }^{47}$

\section{Pro-apoptotic Bcl-2 Proteins}

Bax was initially identified as a Bcl-2-interacting factor capable to antagonize the pro-survival activity of $\mathrm{Bcl}-2 .{ }^{48}$ Based on a sequence homology, Bak (Bcl-2-homologous antagonist/ killer) was identified and characterized as another proapoptotic member of the Bcl-2 protein family. ${ }^{49,50}$ The mitochondrial apoptotic pathway converges on these two pro-apoptotic $\mathrm{Bcl}-2$ proteins either of which is sufficient to drive MOMP in the majority of cells. Bax and Bak are highly redundant and this redundancy has been expected to limit their roles as tumor suppressors. ${ }^{51}$ However, different human malignancies including hematologic tumors exhibit mutated $b a x^{52}$ or $b a k^{53}$ and reduced expression levels of these proapoptotic Bcl-2-family members have been associated with a great number of hematologic malignancies including CLL, follicular lymphoma, MCL and marginal zone B-cell lymphoma. ${ }^{54}$ In line with these observations, genomic ablation of bax impaired myc-driven apoptosis and circumvents the selection of p53 mutations during myc-mediated lymphomagenesis. ${ }^{55}$ Despite having an outwardly normal phenotype, bax $^{-1-}$ or bak ${ }^{-/-}$single knockout mice display a mild hematologic phenotype with only a mild lymphoid hyperplasia, probably owing to the functional redundancy of the two proteins. ${ }^{56,57}$ Double-knockout bak $^{-/-}$bax $^{-/-}$animals display an increase (three- to 10-fold) in both myeloid and lymphoid cells compared with either single bak $^{-/-}$or bax ${ }^{-/-}$ knockouts or wild-type mice. Progressive accumulation of mature B- and T-cells led to massive enlargement of the spleen and lymph nodes and infiltration of parenchymal organs. ${ }^{57}$ Furthermore, bak ${ }^{-/-}$bax $^{-/-}$mice display severe defects in the T-cell development and homeostasis after infection. ${ }^{58}$ Independently, inactivation of bak restored thrombocytopenia caused by $b c /-x /$ deletion, suggesting a crucial role of Bak in platelet lifespan. ${ }^{34}$

\section{BH3-only Proteins}

An expression screen for proteins that bind to $\mathrm{Bcl}-2$ yielded a small novel protein, denoted as Bim, whose only similarity to any known protein was the short (9-amino-acid) $\mathrm{BH} 3$ motif shared by most Bcl-2 homologs. ${ }^{59}$ Sequence analysis of murine cDNAs revealed the presence of three major isoforms (BimEL-196aa, BimL-140aa and BimS-110aa), produced by alternative splicing. ${ }^{59}$ Independently, the same gene was discovered in an ovarian cDNA library, using $\mathrm{Mcl}-1$ as bait, that they initially termed Bod (Bcl-2-related ovarian death agonist). Bim has a critical role during hematopoiesis (Figure 1) and the in vivo function of this protein has received the most attention among the pro-apoptotic Bcl-2 members. Blocking Bim expression by gene deletion or epigenetic silencing has a central role in the pathogenesis or the response to anticancer therapeutics in a number of human hematologic malignancies including Burkitt's lymphoma (BL), MCL and various B-cell non-Hodgkin's lymphomas. ${ }^{60-62}$ Consistent with these observations, gene-targeting experiments of the bim locus in mice demonstrated a crucial role of Bim in the homeostasis of most immune cells. In particular, $\mathrm{bim}^{-/-}$mice have abnormal high numbers of T- and B-cells, macrophages and granulocytes owing to improved apoptosis resistance to several stimuli, including cytokine deprivation, abnormal calcium flux or irradiation. ${ }^{63,64}$ They also show defects in the immune response shutdown as indicated by increased numbers of antibody-secreting plasma cells and the extended survival of activated cytotoxic T-cells after infection. ${ }^{65,66}$ Furthermore, Bim seems to be essential for the apoptosis of autoreactive B- and T-cells (negative selection) resulting in systemic lupus erythematosus-like autoimmune disease in bim $^{-/-}$animals. ${ }^{67,68}$ Moreover, loss of Bim accelerates lymphomagenesis in E $\mu$-myc transgenic mice. ${ }^{69}$

Puma (p53 upregulated modulator of apoptosis) is one of the most potent killers among the $\mathrm{BH} 3$-only proteins, which was initially identified as an antagonist of $\mathrm{Bcl}-2$, induced by p53. ${ }^{70-72}$ In view of the fact that more than half of human tumors comprise p53 mutations, Puma represents an important factor in human cancer as the induction of Puma expression in response to genotoxic anticancer therapeutics is efficiently abrogated in p53-deficient tumors. ${ }^{73}$ Furthermore, $\sim 40 \%$ of primary human BL fail to express detectable levels of Puma and in some tumors this is based on the epigenetic silencing of puma. ${ }^{74}$ puma $^{-/-}$mice show no abnormalities in hematologic tissue development, whereas lymphocytes, myeloid cells and certain other cell types show resistance to apoptosis induced by growth factor withdrawal or DNA damage. ${ }^{75-77}$ Suppression of Puma by shRNAs or its genetic ablation in bim $^{-/-}$mice enhanced myc-driven B-cell lymphomagenesis. ${ }^{77-79}$ In cooperation with Bim, Puma was additionally shown to be involved in homeostasis of mast cells and macrophages. ${ }^{77,80}$ Furthermore, the combined deletion of bim and puma, but not in either single knockout, impaired the elimination of autoreactive T-cells and led to autoimmune reactions in various organs. ${ }^{81}$

After its initial description as a novel phorbol-12-myristate13-acetate-responsive gene in adult T-cell leukemia, Noxa was rediscovered in a differential display approach 
using mRNA from $\gamma$-irradiated wild-type and IRF-1/p53 double-deficient mouse embryonic fibroblasts. ${ }^{82}$ Like Puma, Noxa was initially identified as a primary p53response gene. Noxa has been described as an important determinant of cell death in response to chemotherapy in lymphoid malignancies including CLL, HL, MM and MCL cells. ${ }^{83-86}$ Furthermore, array-based comparative genomic hybridization and gene-expression microarray analysis showed that Noxa is mutated and preferentially silenced in DLBL. ${ }^{60}$ Gene-targeting experiments of noxa in mice displayed defects in T-and B-cell activation and the immune response against viral infection. ${ }^{87,88}$ Furthermore, Noxa was shown to be centrally involved in neutrophils apoptosis. $^{89}$

By utilizing $\mathrm{Bcl}-2$ protein to screen cDNA libraries the $\mathrm{Bcl}-\mathrm{xl} / \mathrm{Bcl}-2$-associated death promoter homolog (Bad) was identified. ${ }^{90}$ Bad was the first $\mathrm{BH}$-only protein to be connected to proximal signal transduction through its differential phosphorylation in response to extracellular survival factors. ${ }^{91}$ In particular, phosphatidylinositol-3-kinase/Akt signaling, a survival pathway frequently hyper-activated in many lymphocytic malignancies, negatively regulates Bad's function. $^{92}$ In line with these observations, bad $^{-/-}$mice develop DLBL of the germinal center or post-germinal center, $\mathrm{B}^{2} 20^{+} \mathrm{CD} 19^{+} \mathrm{B}$-cells expressing the zinc finger transcription factor Bcl-6 (latency >15 months). ${ }^{93}$ Although DLBLs were the most frequent tumor entity observed $(>40 \%)$, bad $^{-/-}$ mice additionally suffered a broad range of different hematologic malignancies. ${ }^{93}$ This is particularly intriguing, as the inactivation of Bad's pro-apoptotic function by phosphorylation appears to have a prominent role in the survival of these lymphocyte populations. ${ }^{92}$

Together, the data obtained by analyzing human tumor samples and in particular the use of transgenic mouse models conclusively support the notion that the Bcl-2 protein family represents a central regulatory node in the development of hematopoietic system.

\section{Bcl-2 Targeting as a Therapeutic Option in Hematologic Malignancies}

Owing to their imbalance expression levels in tumor cells and their capability to regulate MOMP, Bcl-2 proteins have been viewed as promising therapeutic targets in cancer and research efforts have lately been focusing on the development of drugs targeting Bcl-2 proteins. Accordingly, several small-molecule inhibitors of $\mathrm{Bcl}-2$ proteins have been developed and are currently under clinical evaluation (Figure 3 and Table 1). The following paragraphs summarize the results obtained by surveying these small molecules as a therapeutic option with special emphasis on their activity in hematologic malignancies.

\section{Bcl-2 Antisense Oligodeoxynucleotide G3139/Oblimersen}

G3139 (INN, trade name Genasense; also known as Augmerosen or Oblimersen) is an antisense oligodeoxyribonucleotide, specifically targeting $b c l-2$ mRNA. Initial in vitro studies using an 18-base phosphorothioate oligonucleotide complementary to the first six codons of the $b c /-2$
mRNA (G3139) ${ }^{94}$ showed that this molecule selectively and specifically inhibits Bcl-2 expression in the SU-DHL-4 $t(14 ; 18)$-containing lymphoma cell lines. ${ }^{94,95}$ By performing rigorous efficacy, pharmacokinetic and toxicity studies using a number of different lymphoma mouse models ${ }^{95-97}$ the preclinical evaluation of G3139 was completed and further studies were extended into a phase I study for lymphoma patients with high $\mathrm{Bcl}-2$ expression. ${ }^{98}$ Overall the human phase I studies with G3139 demonstrated good efficacy with low toxicity. In particular, tumor regression, improvement in the laboratory parameters, and symptom improvement together with downregulation of the target protein expression were achieved. Based on these promising results several phase II/III clinical trials were initiated (Table 1). A phase II trial of oblimersen sodium as a single agent showed only modest clinical activity in heavily pre-treated patients with advanced CLL. ${ }^{99}$ However, a separate phase III study of fludarabine plus cyclophosphamide with or without oblimersen showed a 5-year survival benefit in a post hoc analysis of patients with CLL who achieved complete (CR) or partial remission (PR). ${ }^{100}$ Oblimersen in combination with rituximab was tested in a phase II trial in non-Hodgkin lymphoma. This study revealed a CR in $23 \%$ patients, a PR in $19 \%$ patients and $28 \%$ of patients showed a minimal response or a stable disease (SD). ${ }^{101}$ Another phase II trial was conducted for the treatment of AML with a combination of oblimersen and gemtuzumab ozogamicin with $10 \%$ patients achieved a CR and $15 \%$ patients achieved a PR. ${ }^{102}$ Oblimersen was also tested in combination with dexamethasone and thalidomide in a phase II trial for the treatment of relapsed MM patients. Fifty five percent of patients had objective responses, including 2/36 CRs, 4/36 near CRs, and 12/36 PR and 6/36 patients had minimal responses. ${ }^{103}$ However, a randomised phase III trial of oblimersen in combination with other drugs in advanced MM, melanoma or prostate cancer did not show a statistical difference in overall survival. ${ }^{104-106}$ Based on these results oblimersen was not approved as a therapeutic option by the FDA. ${ }^{107}$ Though, oblimersen efficiently downregulated $\mathrm{Bcl}-2$ in cell culture and thereby effectively reduced lymphoma cell survival the lack of efficiency in primary tumors might be a result of insufficient drug delivery in patients. ${ }^{108}$ Furthermore, those studies demonstrated a long-term benefit for some patients after completing the study and encouraged a renewal of the drug approval, which is still ongoing.

\section{Gossypol}

Gossypol, a natural phenol derived from the cotton plant, was characterized as a specific antagonist of $\mathrm{Bcl}-\mathrm{xl} .{ }^{109}$ Further studies showed that gossypol acts as a pan-Bcl-2-family inhibitor, capable of binding and inhibiting most antiapoptotic Bcl-2-family members. ${ }^{110}$ Preclinical evaluation of gossypol revealed a potent anti-tumor activity by activating the mitochondrial apoptotic pathway in DLBL, ${ }^{111} \mathrm{CML}$ (chronic myeloid leukemia), ${ }^{112}$ CLL, ${ }^{113}$ and non-Hodgkin lymphoma. ${ }^{114}$ Based on these analyses an orally-bioavailable enantiomer of gossypol, AT-101, was evaluated in phase II clinical trials for the treatment of prostate and lung cancer as single agent or in combination with conventional 
chemotherapeutics (Table 1). However, these efforts did not show convincing clinical activity. ${ }^{115-119}$ Notably, the most common toxicity was observed in hematologic compartment, suggesting a more potent toxic effect on hematologic malignancies. ${ }^{115}$ Phase II trials for the treatment of hematological malignancies are still in progress. ${ }^{120}$

\section{Obatoclax (GX15-070)}

Obatoclax, a pan-Bcl-2-family inhibitor, was developed from a natural lead compound that potently disrupted the interaction of members of the Bcl-2-family in a functional screen. ${ }^{121}$ As a single agent, obatoclax possesses pronounced anticancer activity in cell lines or primary cells derived from patients suffering from different hematologic malignancies including $\mathrm{AML},{ }^{122}$ mast cell leukemia, ${ }^{123} \mathrm{ALL}^{124} \mathrm{CLL},{ }^{125} \mathrm{MM},{ }^{126}$ and $\mathrm{HL}$ (Hodgkin Lymphoma). ${ }^{127}$ Albeit promising results were obtained in vitro and in vivo mouse models, phase I clinical trials for the treatment of AML, CLL, ALL, lymphoma and solid tumors as well as phase II clinical trials for the treatment of $\mathrm{HL}$ and myelofibrosis revealed a clinical activity as single agent only in a minority of patients (Table 1). ${ }^{128-132}$ However, further phase I trials for the combined treatment show very promising clinical activity of obatoclax in specific treatment protocols, such as the combination with bortezomib in $\mathrm{MCL}^{133}$ and $\mathrm{MM}^{134}$ with $3 / 12$ and $4 / 10$ patients showing a clinical response, respectively.

\section{ABT-737/ABT-263 (Navitoclax)/ABT-199 (GDC-0199)}

A high-throughput NMR-based method was used to screen a chemical library to identify small molecules that bind to the hydrophobic BH3-binding groove of $\mathrm{Bcl}-\mathrm{xl}$. The resultant compound ABT-737, developed by Abbott Laboratories (North Chicago, IL, USA), bound with high affinity (Ki $\leq 1 \mathrm{nM})$ to $\mathrm{Bcl}-\mathrm{xl}, \mathrm{Bcl}-2$ and $\mathrm{Bcl}-\mathrm{w}$, but not to the less-homologous proteins $\mathrm{Bcl}-\mathrm{b}, \mathrm{Mcl}-1$ and $\mathrm{A} 1{ }^{1{ }^{135}}$ Further evaluation of its antitumor activity showed that ABT-737 displayed potent singleagent activity against a subset of cell lines representing lymphoid malignancies. ${ }^{135}$ In combination with conventional chemotherapeutics, ABT-737 was shown to potently induce apoptosis in HL, ${ }^{136} \mathrm{MM},{ }^{137} \mathrm{AMC}^{138}$ and $\mathrm{CLL}{ }^{139}$ and also solid tumors such as non-small cell lung cancer (NSCLC). ${ }^{135}$ In addition to established human tumor cell lines, ABT-737 effectively induced apoptosis in primary patient-derived lymphoma and CLL cells ex vivo. ${ }^{135}$

However, the prospects for ABT-737 as a therapeutic agent have been hampered by its poor physiochemical and pharmaceutical properties. This compound is not orally bioavailable and its low aqueous solubility makes formulation for i.v. delivery challenging. However, the impressive biological activity of ABT-737 encouraged research to develop an orally-bioavailable compound. On the basis of various pharmacokinetic/pharmacodynamic models and animal studies ABT-263 (Navitoclax; Figure 3), an orraly-bioavailable Bad-like BH3 mimetic (Kis of $<1 \mathrm{nM}$ for Bcl-2, Bcl-xl, and Bcl-w) was generated. ABT-263 disrupts $\mathrm{Bcl}-2 / \mathrm{Bcl}-\mathrm{xl}$ interactions with pro-death proteins (e.g. Bim), leading to the initiation of apoptosis within $2 \mathrm{~h}$ post treatment. ${ }^{140}$ Initial analyses showed that the oral administration of ABT-263 alone induces complete tumor regressions in xenograft models of small cell lung cancer (SCLC) and ALL. In xenograft models of aggressive B-cell lymphoma and MM ABT-263 promoted significant efficacy of clinically relevant chemotherapeutic regimens. ${ }^{140}$ A detailed activity screen revealed that ABT-263 enhances the response of multiple chemotherapeutic regimens, for example, rituximab, rapamycine, rituximabcyclophosphamide-adriamycin-vincristine-prednisone, and bortezomib, in several models of hematologic malignancies. ${ }^{141}$ However, owing to the crucial role of $\mathrm{Bcl}-\mathrm{xl}$ in platelet homeostasis $^{34}$ the therapeutic use of ABT-263 was associated with transient thrombocytopenia in preclinical trials. $^{142}$

Based on the results obtained by ABT-737 and ABT-263, Abbott Laboratories has recently developed a high-affinity Bcl-2-selective BH3 mimetic, ABT-199 (GDC-0199), which spared human platelets in vitro and dog platelets in vivo. ${ }^{143}$ Tumor regression was achieved for xenografts of human lymphoma cell lines. ABT-199 was as effective as ABT-737 in prolonging survival of immuno-competent mice bearing aggressive progenitor cell lymphomas (derived from bitransgenic $\mathrm{myc} / \mathrm{bcl}-2$ mice) without causing thrombocytopenia. ${ }^{144}$ Furthermore, ABT-199 was identified as a promising therapeutic option for the treatment of $\mathrm{t}(11 ; 14) \mathrm{MM}^{145}$ and AML. ${ }^{146}$ More strikingly, the first clinical trial using a single dose of ABT-199 in three patients with refractory CLL resulted in a rapid tumor lysis within $24 \mathrm{~h}$ in 3 of 3 patients. ${ }^{143}$

Together the data obtained by using different pharmacological inhibitors of $\mathrm{Bcl}-2$ indicated a marked susceptibility of hematologic malignancies towards the Bcl-2-targeting protocols (Table 1).

\section{Perspectives and Restrictions}

There are not many anticancer therapeutics that are as exclusively characterized as Bcl-2-targeting strategies concerning their specificity toward the designated target and the mode of their interference with cellular actions and cell death. This is indeed based on our increasing knowledge about Bcl-2 protein family in the last 20 years, which finally has entered the translational stage in the last couple of years. One major aspect about $\mathrm{Bcl}-2$ proteins is their crucial role in the development and the homeostasis of cells of hematopoietic origin. Previous data showed that an imbalanced Bcl-2 protein level causally determines hematologic malignant progression and accordingly targeting the $\mathrm{Bcl}-2$ protein family has been proven to be successful, in particular, in hematologic malignancies. However, manipulations in their function or abundance in the healthy hematologic system may result in fatal changes in this tissue compartment. ${ }^{147}$ Accordingly, this may indicate that in non-hematologic malignancies Bcl-2targeting strategies should be used with specific caution concerning the functionality and homeostasis of the hematologic system. Alternatively, given the cell type-specific role of some Bcl-2-family members and a more abundant role of other members a highly selective targeting strategy is necessary to avoid severe on-target side effects in the development of other tissues. However, agents targeting the $\mathrm{Bcl}-2$ protein family have been generally shown to be a potent killer of tumor cells derived from hematologic malignancies 
and accumulating evidence supports the idea that the treatment of other cancer entities may strongly benefit from the Bcl-2-antagonizing protocols in combination with other chemotherapy regimens. The knowledge of how and in combination with which additional chemotherapeutics Bcl-2antagonizing protocols provoke a potent anticancer effect will strongly foster the clinical evaluation of Bcl-2-targeting strategies.

\section{Conflict of Interest}

The authors declare no conflict of interest

Acknowledgements. This work was supported by a grant from the Deutsche Forschungsgemeinschaft (DFG), KFO 286-RP3, SFB 832-A9 and Köln Fortune Program/Faculty of Medicine, University of Cologne.

1. Adams JM, Cory S. The Bcl-2 apoptotic switch in cancer development and therapy Oncogene 2007; 26: 1324-1337.

2. Hanahan D, Weinberg RA. Hallmarks of cancer: the next generation. Cell 2011; 144 646-674.

3. Sachs $L$. The control of hematopoiesis and leukemia: from basic biology to the clinic Proc Natl Acad Sci USA 1996; 93: 4742-4749.

4. Wickremasinghe RG, Hoffbrand AV. Biochemical and genetic control of apoptosis: relevance to normal hematopoiesis and hematological malignancies. Blood 1999; 93 $3587-3600$

5. Renault TT, Chipuk JE. Getting away with murder: how does the BCL-2 family of proteins kill with immunity? Ann N Y Acad Sci 2013; 1285: 59-79.

6. Debatin KM. Role of apoptosis in congenital hematologic disorders and bone marrow failure. Rev Clin Exp Hematol 2003; 7: 57-71.

7. Tsujimoto Y, Finger LR, Yunis J, Nowell PC, Croce CM. Cloning of the chromosome breakpoint of neoplastic B cells with the $t(14 ; 18)$ chromosome translocation. Science 1984; 226: 1097-1099.

8. Nakayama K, Nakayama K, Negishi I, Kuida K, Shinkai Y, Louie MC et al. Disappearance of the lymphoid system in Bcl-2 homozygous mutant chimeric mice. Science 1993; 261 1584-1588.

9. Veis DJ, Sorenson CM, Shutter JR, Korsmeyer SJ. Bcl-2-deficient mice demonstrate fulminant lymphoid apoptosis, polycystic kidneys, and hypopigmented hair. Cell 1993; 75 229-240.

10. Matsuzaki Y, Nakayama K, Nakayama K, Tomita T, Isoda M, Loh DY et al. Role of bcl-2 in the development of lymphoid cells from the hematopoietic stem cell. Blood 1997; 89: 853-862.

11. Strasser A, Harris AW, Cory S. bcl-2 transgene inhibits T cell death and perturbs thymic self-censorship. Cell 1991; 67: 889-899.

12. Strasser A, Whittingham S, Vaux DL, Bath ML, Adams JM, Cory S et al. Enforced BCL2 expression in B-lymphoid cells prolongs antibody responses and elicits autoimmun disease. Proc Natl Acad Sci USA 1991; 88: 8661-8665.

13. Strasser A, Harris AW, Corcoran LM, Cory S. Bcl-2 expression promotes B- but not T-lymphoid development in scid mice. Nature 1994; 368: 457-460.

14. Vaux DL, Cory S, Adams JM. Bcl-2 gene promotes haemopoietic cell survival and cooperates with c-myc to immortalize pre-B cells. Nature 1988; 335: 440-442.

15. Kozopas KM, Yang T, Buchan HL, Zhou P, Craig RW. MCL1 a gene expressed in programmed myeloid cell differentiation, has sequence similarity to BCL2. Proc Natl Acad Sci USA 1993; 90: 3516-3520.

16. Okita H, Umezawa A, Fukuma M, Ando T, Urano F, Sano M et al. Acute myeloid leukemia possessing jumping translocation is related to highly elevated levels of EAT/mcl-1, a Bcl-2 related gene with anti-apoptotic functions. Leuk Res 2000; 24: 73-77.

17. Khoury JD, Medeiros LJ, Rassidakis GZ, McDonnell TJ, Abruzzo LV, Lai R. Expression of $\mathrm{Mcl}-1$ in mantle cell lymphoma is associated with high-grade morphology, a high proliferative state, and p53 overexpression. J Pathol 2003; 199: 90-97.

18. Wenzel SS, Grau M, Mavis $C$, Hailfinger S, Wolf A, Madle H et al. MCL1 is deregulated in subgroups of diffuse large B-cell lymphoma. Leukemia 2012; 27: 1381-1390.

19. Kuramoto K, Sakai A, Shigemasa K, Takimoto Y, Asaoku H, Tsujimoto T et al. High expression of MCL1 gene related to vascular endothelial growth factor is associated with poor outcome in non-Hodgkin's lymphoma. Br J Haematol 2002; 116: 158-161.

20. Zhang B, Gojo I, Fenton RG. Myeloid cell factor-1 is a critical survival factor for multiple myeloma. Blood 2002; 99: 1885-1893.

21. Glaser SP, Lee EF, Trounson E, Bouillet P, Wei A, Fairlie WD et al. Anti-apoptotic Mcl-1 is essential for the development and sustained growth of acute myeloid leukemia. Genes Dev 2012; 26: 120-125

22. Rinkenberger JL, Horning S, Klocke B, Roth K, Korsmeyer SJ. Mcl-1 deficiency results in peri-implantation embryonic lethality. Genes Dev 2000; 14: 23-27.
23. Opferman JT, Letai A, Beard C, Sorcinelli MD, Ong CC, Korsmeyer SJ. Development and maintenance of B and T lymphocytes requires antiapoptotic MCL-1. Nature 2003; 426: 671-676.

24. Vikstrom I, Carotta S, Luthje K, Peperzak V, Jost PJ, Glaser S et al. Mcl-1 is essential for germinal center formation and B cell memory. Science 2010; 330: 1095-1099.

25. Peperzak V, Vikstrom I, Walker J, Glaser SP, LePage M, Coquery CM et al. Mcl-1 is essential for the survival of plasma cells. Nat Immunol 2013; 14: 290-297.

26. Dzhagalov I St, John A, He YW. The antiapoptotic protein Mcl-1 is essential for the survival of neutrophils but not macrophages. Blood 2007; 109: 1620-1626.

27. Lilla JN, Chen CC, Mukai K, BenBarak MJ, Franco CB, Kalesnikoff J et al. Reduced mast cell and basophil numbers and function in Cpa3-Cre; Mcl-1fl/fl mice. Blood 2011; 118: $6930-6938$

28. Opferman JT, Iwasaki H, Ong CC, Suh H, Mizuno S, Akashi $\mathrm{K}$ et al. Obligate role of anti-apoptotic MCL-1 in the survival of hematopoietic stem cells. Science 2005; 307: 1101-1104.

29. Kelly GL, Grabow S, Glaser SP, Fitzsimmons L, Aubrey BJ, Okamoto T et al. Targeting of MCL-1 kills MYC-driven mouse and human lymphomas even when they bear mutations in p53. Genes Dev 2014; 28: 58-70.

30. Zhou P, Levy NB, Xie H, Qian L, Lee CY, Gascoyne RD et al. MCL1 transgenic mice exhibit a high incidence of B-cell lymphoma manifested as a spectrum of histologic subtypes. Blood 2001; 97: 3902-3909.

31. Boise LH, Gonzalez-Garcia M, Postema CE, Ding L, Lindsten T, Turka LA et al. bcl-x, a bcl-2-related gene that functions as a dominant regulator of apoptotic cell death. Cell 1993; 74: 597-608.

32. Horita M, Andreu EJ, Benito A, Arbona C, Sanz C, Benet I et al. Blockade of the Bcr-Ab kinase activity induces apoptosis of chronic myelogenous leukemia cells by suppressing signal transducer and activator of transcription 5-dependent expression of $\mathrm{Bcl}-\mathrm{xL}$. $J$ Exp Med 2000; 191: 977-984.

33. Motoyama N, Wang F, Roth KA, Sawa H, Nakayama K, Nakayama K et al. Massive cell death of immature hematopoietic cells and neurons in Bcl-x-deficient mice. Science 1995; 267: 1506-1510.

34. Mason KD, Carpinelli MR, Fletcher Jl, Collinge JE, Hilton AA, Ellis S et al. Programmed anuclear cell death delimits platelet life span. Cell 2007; 128: 1173-1186.

35. Kelly PN, Grabow S, Delbridge AR, Strasser A, Adams JM. Endogenous Bcl-xL is essential for Myc-driven lymphomagenesis in mice. Blood 2011; 118: 6380-6386.

36. Lin EY, Orlofsky A, Berger MS, Prystowsky MB. Characterization of A1, a nove hemopoietic-specific early-response gene with sequence similarity to bcl-2. J Immunol 1993; 151: 1979-1988.

37. Nagy B, Lundan T, Larramendy ML, Aalto Y, Zhu Y, Niini T et al. Abnormal expression of apoptosis-related genes in haematological malignancies: overexpression of MYC is poor prognostic sign in mantle cell lymphoma. Br J Haematol 2003; 120: 434-441.

38. Mahadevan D, Spier C, Della Croce K, Miller S, George B, Riley C et al. Transcript profiling in peripheral T-cell lymphoma, not otherwise specified, and diffuse large B-cell lymphoma identifies distinct tumor profile signatures. Mol Cancer Ther 2005; 4 : 1867-1879.

39. Piva R, Pellegrino E, Mattioli M, Agnelli L, Lombardi L, Boccalatte $F$ et al. Functional validation of the anaplastic lymphoma kinase signature identifies CEBPB and BCL2A1 as critical target genes. J Clin Invest 2006; 116: 3171-3182.

40. Monti S, Savage KJ, Kutok JL, Feuerhake F, Kurtin P, Mihm M et al. Molecular profiling of diffuse large B-cell lymphoma identifies robust subtypes including one characterized by host inflammatory response. Blood 2005; 105: 1851-1861.

41. Xiang Z, Ahmed AA, Moller C, Nakayama K, Hatakeyama S, Nilsson G. Essential role of the prosurvival bcl-2 homologue $A 1$ in mast cell survival after allergic activation. $J$ Exp Med 2001; 194: 1561-1569.

42. Tomayko MM, Cancro MP. Long-lived B cells are distinguished by elevated expression of A1. J Immunol 1998; 160: 107-111.

43. Hamasaki A, Sendo F, Nakayama K, Ishida N, Negishi I, Nakayama K et al. Accelerated neutrophil apoptosis in mice lacking $A 1-a$, a subtype of the bcl-2-related $A 1$ gene. J Exp Med 1998; 188: 1985-1992.

44. Oberdoerffer P, Kanellopoulou C, Heissmeyer V, Paeper C, Borowski C, Aifantis I et al. Efficiency of RNA interference in the mouse hematopoietic system varies between cell types and developmental stages. Mol Cell Biol 2005; 25: 3896-3905.

45. Ottina E, Grespi F, Tischner D, Soratroi C, Geley S, Ploner A et al. Targeting antiapoptotic $\mathrm{A} 1 / \mathrm{Bfl}-1$ by in vivo RNAi reveals multiple roles in leukocyte development in mice. Blood 2012; 119: 6032-6042.

46. Verschelde C, Michonneau D, Trescol-Biemont MC, Berberich I, Schimpl A Bonnefoy-Berard N. Overexpression of the antiapoptotic protein A1 promotes the survival of double positive thymocytes awaiting positive selection. Cell Death Differ 2006; 13: $1213-1221$

47. Chuang PI, Morefield S, Liu CY, Chen S, Harlan JM, Willerford DM. Perturbation of B-cell development in mice overexpressing the Bcl-2 homolog A1. Blood 2002; 99: 3350-3359.

48. Oltvai ZN, Milliman $\mathrm{CL}$, Korsmeyer SJ. Bcl-2 heterodimerizes in vivo with a conserved homolog, Bax, that accelerates programmed cell death. Cell 1993; 74: 609-619.

49. Chittenden T, Harrington EA, O'Connor R, Flemington C, Lutz RJ, Evan Gl et al. Induction of apoptosis by the Bcl-2 homologue Bak. Nature 1995; 374: 733-736.

50. Kiefer MC, Brauer MJ, Powers VC, Wu JJ, Umansky SR, Tomei LD et al. Modulation of apoptosis by the widely distributed Bcl-2 homologue Bak. Nature 1995; 374: 736-739. 
51. Adams JM, Cory S. Bcl-2-regulated apoptosis: mechanism and therapeutic potential. Curr Opin Immunol 2007; 19: 488-496.

52. Meijerink JP, Mensink EJ, Wang K, Sedlak TW, Sloetjes AW, de Witte T et al. Hematopoietic malignancies demonstrate loss-of-function mutations of BAX. Blood 1998; 91: 2991-2997.

53. Kondo S, Shinomura Y, Miyazaki Y, Kiyohara T, Tsutsui S, Kitamura $S$ et al. Mutations of the bak gene in human gastric and colorectal cancers. Cancer Res 2000; 60: 4328-4330.

54. Agarwal B, Naresh KN. Bcl-2 family of proteins in indolent B-cell non-Hodgkin's lymphoma: study of 116 cases. Am J Hematol 2002; 70: 278-282.

55. Eischen CM, Roussel MF, Korsmeyer SJ, Cleveland JL. Bax loss impairs Myc-induced apoptosis and circumvents the selection of p53 mutations during Myc-mediated lymphomagenesis. Mol Cell Biol 2001; 21: 7653-7662.

56. Knudson CM, Tung KS, Tourtellotte WG, Brown GA, Korsmeyer SJ. Bax-deficient mice with lymphoid hyperplasia and male germ cell death. Science 1995; 270: 96-99.

57. Lindsten T, Ross AJ, King A, Zong WX, Rathmell JC, Shiels HA et al. The combined functions of proapoptotic Bcl-2 family members bak and bax are essential for normal development of multiple tissues. Mol Cell 2000; 6: 1389-1399.

58. Rathmell JC, Lindsten T, Zong WX, Cinalli RM, Thompson CB. Deficiency in Bak and Bax perturbs thymic selection and lymphoid homeostasis. Nat Immunol 2002; 3: 932-939.

59. O'Connor L, Strasser A, O'Reilly LA, Hausmann G, Adams JM, Cory S et al. Bim: a novel member of the Bcl-2 family that promotes apoptosis. EMBO J 1998; 17: 384-395.

60. Mestre-Escorihuela C, Rubio-Moscardo F, Richter JA, Siebert R, Climent J, Fresquet V et al. Homozygous deletions localize novel tumor suppressor genes in B-cell lymphomas. Blood 2007; 109: 271-280.

61. Pinon JD, Labi V, Egle A, Villunger A. Bim and Bmf in tissue homeostasis and malignant disease. Oncogene 2008; 27(Suppl 1): S41-S52.

62. Tagawa H, Suguro M, Tsuzuki S, Matsuo K, Karnan S, Ohshima K et al. Comparison of genome profiles for identification of distinct subgroups of diffuse large B-cell lymphoma. Blood 2005; 106: 1770-1777.

63. Bouillet P, Metcalf D, Huang DC, Tarlinton DM, Kay TW, Kontgen F et al. Proapoptotic Bcl-2 relative Bim required for certain apoptotic responses, leukocyte homeostasis, and to preclude autoimmunity. Science 1999; 286: 1735-1738.

64. Villunger A, Scott $C$, Bouillet $P$, Strasser $A$. Essential role for the $B H 3$-only protein Bim but redundant roles for $\mathrm{Bax}, \mathrm{Bcl}-2$, and $\mathrm{Bcl}-\mathrm{w}$ in the control of granulocyte survival. Blood 2003; 101: 2393-2400.

65. Hildeman DA, Zhu Y, Mitchell TC, Bouillet P, Strasser A, Kappler J et al. Activated T cell death in vivo mediated by proapoptotic bcl-2 family member bim. Immunity 2002; 16 : 759-767.

66. Pellegrini M, Belz G, Bouillet $P$, Strasser A. Shutdown of an acute T cell immune response to viral infection is mediated by the proapoptotic $\mathrm{Bcl}-2$ homology 3-only protein Bim. Proc Natl Acad Sci USA 2003; 100: 14175-14180.

67. Bouillet P, Purton JF, Godfrey DI, Zhang LC, Coultas L, Puthalakath $\mathrm{H}$ et al. BH3-only $\mathrm{Bcl}-2$ family member Bim is required for apoptosis of autoreactive thymocytes. Nature 2002; 415: 922-926.

68. Villunger A, Marsden VS, Zhan Y, Erlacher M, Lew AM, Bouillet P et al. Negative selection of semimature $\mathrm{CD} 4(+) 8(-) \mathrm{HSA}+$ thymocytes requires the BH3-only protein Bim but is independent of death receptor signaling. Proc Natl Acad Sci USA 2004; 101: 7052-7057.

69. Egle A, Harris AW, Bouillet P, Cory S. Bim is a suppressor of Myc-induced mouse B cell leukemia. Proc Natl Acad Sci USA 2004; 101: 6164-6169.

70. Nakano K, Vousden KH. PUMA a novel proapoptotic gene, is induced by p53. Mol Cell 2001; 7: 683-694.

71. Yu J, Zhang L, Hwang PM, Kinzler KW, Vogelstein B. PUMA induces the rapid apoptosis of colorectal cancer cells. Mol Cell 2001; 7: 673-682.

72. Han J, Flemington C, Houghton AB, Gu Z, Zambetti GP, Lutz RJ et al. Expression of bbc3, a pro-apoptotic BH3-only gene, is regulated by diverse cell death and survival signals. Proc Natl Acad Sci USA 2001; 98: 11318-11323.

73. Yu J, Zhang L. The transcriptional targets of $\mathrm{p} 53$ in apoptosis control. Biochem Biophys Res Commun 2005; 331: 851-858.

74. Garrison SP, Jeffers JR, Yang C, Nilsson JA, Hall MA, Rehg JE et al. Selection against PUMA gene expression in Myc-driven B-cell lymphomagenesis. Mol Cell Biol 2008; 28: 5391-5402.

75. Villunger A, Michalak EM, Coultas L, Mullauer F, Bock G, Ausserlechner MJ et al. p53- and drug-induced apoptotic responses mediated by $\mathrm{BH} 3$-only proteins puma and noxa. Science 2003; 302: 1036-1038.

76. Jeffers JR, Parganas E, Lee Y, Yang C, Wang J, Brennan J et al. Puma is an essential mediator of p53-dependent and -independent apoptotic pathways. Cancer Cell 2003; 4: 321-328.

77. Erlacher M, Labi V, Manzl C, Bock G, Tzankov A, Hacker G et al. Puma cooperates with $\mathrm{Bim}$, the rate-limiting $\mathrm{BH} 3$-only protein in cell death during lymphocyte development, in apoptosis induction. J Exp Med 2006; 203: 2939-2951.

78. Hemann MT, Zilfou JT, Zhao Z, Burgess DJ, Hannon GJ, Lowe SW. Suppression of tumorigenesis by the p53 target PUMA. Proc Natl Acad Sci USA 2004; 101: 9333-9338.

79. Michalak EM, Jansen ES, Happo L, Cragg MS, Tai L, Smyth GK et al. Puma and to a lesser extent Noxa are suppressors of Myc-induced lymphomagenesis. Cell Death Differ 2009; 16: 684-696.
80. Garrison SP, Phillips DC, Jeffers JR, Chipuk JE, Parsons MJ, Rehg JE et al. Genetically defining the mechanism of Puma- and Bim-induced apoptosis. Cell Death Differ 2012; 19: 642-649.

81. Gray DH, Kupresanin F, Berzins SP, Herold MJ, O'Reilly LA, Bouillet P et al. The BH3only proteins Bim and Puma cooperate to impose deletional tolerance of organ-specific antigens. Immunity 2012; 37: 451-462.

82. Oda E, Ohki R, Murasawa H, Nemoto J, Shibue T, Yamashita T et al. Noxa, a BH3-only member of the Bcl-2 family and candidate mediator of p53-induced apoptosis. Science 2000; 288: 1053-1058

83. Gomez-Bougie P, Wuilleme-Toumi S, Menoret E, Trichet V, Robillard N, Philippe M et al. Noxa up-regulation and $\mathrm{Mcl}-1$ cleavage are associated to apoptosis induction by bortezomib in multiple myeloma. Cancer Res 2007; 67: 5418-5424.

84. Perez-Galan P, Roue G, Villamor N, Montserrat E, Campo E, Colomer D. The proteasome inhibitor bortezomib induces apoptosis in mantle-cell lymphoma through generation of ROS and Noxa activation independent of p53 status. Blood 2006; 107 257-264.

85. Qin JZ, Ziffra J, Stennett L, Bodner B, Bonish BK, Chaturvedi V et al. Proteasome inhibitors trigger NOXA-mediated apoptosis in melanoma and myeloma cells. Cancer Res 2005; 65: 6282-6293.

86. Brinkmann K, Zigrino $P$, Witt A, Schell M, Ackermann L, Broxtermann $P$ et al. Ubiquitin $\mathrm{C}$-terminal hydrolase-L1 potentiates cancer chemosensitivity by stabilizing NOXA. Cell Rep 2013; 3: 881-891.

87. Wensveen FM, Derks IA, van Gisbergen KP, de Bruin AM, Meijers JC, Yigittop H et al. $\mathrm{BH}$-only protein Noxa regulates apoptosis in activated $\mathrm{B}$ cells and controls high-affinity antibody formation. Blood 2012; 119: 1440-1449.

88. Wensveen FM, Klarenbeek PL, van Gisbergen KP, Pascutti MF, Derks IA, van Schaik BD et al. Pro-apoptotic protein Noxa regulates memory $T$ cell population size and protects against lethal immunopathology. J Immunol 2013; 190: 1180-1191.

89. Kirschnek S, Vier J, Gautam S, Frankenberg T, Rangelova S, Eitz-Ferrer $\mathrm{P}$ et al. Molecular analysis of neutrophil spontaneous apoptosis reveals a strong role for the pro-apoptotic BH3-only protein Noxa. Cell Death Differ 2011; 18: 1805-1814.

90. Yang E, Zha J, Jockel J, Boise LH, Thompson CB, Korsmeyer SJ. Bad a heterodimeric partner for Bcl-XL and Bcl-2, displaces Bax and promotes cell death. Cell 1995; 80: 285-291.

91. Zha J, Harada H, Yang E, Jockel J, Korsmeyer SJ. Serine phosphorylation of death agonist $B A D$ in response to survival factor results in binding to 14-3-3 not $B C L-X(L)$. Cell 1996; 87: 619-628.

92. Datta SR, Dudek H, Tao X, Masters S, Fu H, Gotoh Y et al. Akt phosphorylation of BAD couples survival signals to the cell-intrinsic death machinery. Cell 1997; 91: 231-241.

93. Ranger AM, Zha J, Harada H, Datta SR, Danial NN, Gilmore AP et al. Bad-deficient mice develop diffuse large B cell lymphoma. Proc Natl Acad Sci USA 2003; 100: 9324-9329.

94. Kitada S, Miyashita T, Tanaka S, Reed JC. Investigations of antisense oligonucleotides targeted against bcl-2 RNAs. Antisense Res Dev 1993; 3: 157-169.

95. Cotter FE, Johnson P, Hall P, Pocock C, al Mahdi N, Cowell JK et al. Antisense oligonucleotides suppress B-cell lymphoma growth in a SCID-hu mouse model. Oncogene 1994; 9: 3049-3055.

96. Devereux S, Cotter FE. Anti-sense and gene therapy approaches to the treatment of lymphomas. Baillieres Clin Haematol 1996; 9: 819-834.

97. Pocock CF, Malone M, Booth M, Evans M, Morgan G, Greil J et al. BCL-2 expression by leukaemic blasts in a SCID mouse model of biphenotypic leukaemia associated with the $\mathrm{t}(4 ; 11)(\mathrm{q} 21 ; \mathrm{q} 23)$ translocation. Br J Haematol 1995; 90: 855-867.

98. Cotter FE, Waters J, Cunningham D. Human Bcl-2 antisense therapy for lymphomas. Biochim Biophys Acta 1999; 1489: 97-106.

99. O'Brien SM, Cunningham CC, Golenkov AK, Turkina AG, Novick SC, Rai KR. Phase I to II multicenter study of oblimersen sodium, a Bcl-2 antisense oligonucleotide, in patients with advanced chronic lymphocytic leukemia. J Clin Oncol 2005; 23: 7697-7702.

100. O'Brien S, Moore JO, Boyd TE, Larratt LM, Skotnicki AB, Koziner B et al. 5-year survival in patients with relapsed or refractory chronic lymphocytic leukemia in a randomized, phase III trial of fludarabine plus cyclophosphamide with or without oblimersen. $J$ Clin Oncol 2009; 27: 5208-5212.

101. Pro B, Leber B, Smith M, Fayad L, Romaguera J, Hagemeister F et al. Phase ॥ multicenter study of oblimersen sodium, a Bcl-2 antisense oligonucleotide, in combination with rituximab in patients with recurrent B-cell non-Hodgkin lymphoma. $\mathrm{Br} \mathrm{J}$ Haematol 2008; 143: 355-360.

102. Moore J, Seiter K, Kolitz J, Stock W, Giles F, Kalaycio M et al. A Phase II study of Bcl-2 antisense (oblimersen sodium) combined with gemtuzumab ozogamicin in older patients with acute myeloid leukemia in first relapse. Leuk Res 2006; 30: 777-783.

103. Badros AZ, Goloubeva O, Rapoport AP, Ratterree B, Gahres N, Meisenberg B et al Phase II study of $\mathrm{G} 3139$, a Bcl-2 antisense oligonucleotide, in combination with dexamethasone and thalidomide in relapsed multiple myeloma patients. J Clin Oncol 2005; 23: 4089-4099.

104. Bedikian AY, Millward M, Pehamberger H, Conry R, Gore M, Trefzer U et al. Bcl-2 antisense (oblimersen sodium) plus dacarbazine in patients with advanced melanoma: the Oblimersen Melanoma Study Group. J Clin Oncol 2006; 24: 4738-4745.

105. Chanan-Khan AA, Niesvizky R, Hohl RJ, Zimmerman TM, Christiansen NP, Schiller GJ et al. Phase III randomised study of dexamethasone with or without oblimersen sodium for patients with advanced multiple myeloma. Leuk Lymphoma 2009; 50: 559-565. 
106. Sternberg CN, Dumez H, Van Poppel H, Skoneczna I, Sella A, Daugaard G et al. Docetaxel plus oblimersen sodium (Bcl-2 antisense oligonucleotide): an EORTC multicenter, randomized phase II study in patients with castration-resistant prostate cancer. Ann Oncol 2009; 20: 1264-1269.

107. Advani PP, Paulus A, Masood A, Sher T, Chanan-Khan A. Pharmacokinetic evaluation of oblimersen sodium for the treatment of chronic lymphocytic leukemia. Expert Opin Drug Metab Toxicol 2011; 7: 765-774.

108. Davids MS, Letai A. Targeting the B-cell lymphoma/leukemia 2 family in cancer. J Clin Oncol 2012; 30: 3127-3135.

109. Kitada S, Leone M, Sareth S, Zhai D, Reed JC, Pellecchia M. Discovery, characterization, and structure-activity relationships studies of proapoptotic polyphenols targeting B-cell lymphocyte/leukemia-2 proteins. J Med Chem 2003; 46: 4259-4264.

110. Zhai D, Jin C, Satterthwait AC, Reed JC. Comparison of chemical inhibitors of antiapoptotic Bcl-2-family proteins. Cell Death Differ 2006; 13: 1419-1421.

111. Mohammad RM, Wang S, Aboukameel A, Chen B, Wu X, Chen J et al. Preclinical studies of a nonpeptidic small-molecule inhibitor of $\mathrm{Bcl}-2$ and $\mathrm{BCl}-\mathrm{X}(\mathrm{L})$ [(-)-gossypol] against diffuse large cell lymphoma. Mol Cancer Ther 2005; 4: 13-21.

112. Meng Y, Li Y, Li J, Li H, Fu J, Liu Y et al. (-)Gossypol and its combination with imatinib induce apoptosis in human chronic myeloid leukemic cells. Leuk Lymphoma 2007; 48 2204-2212.

113. Balakrishnan K, Burger JA, Wierda WG, Gandhi V. AT-101 induces apoptosis in CLL B cells and overcomes stromal cell-mediated Mcl-1 induction and drug resistance. Blood 2009; 113: 149-153.

114. Li ZM, Jiang WQ, Zhu ZY, Zhu XF, Zhou JM, Liu ZC et al. Synergistic cytotoxicity of Bcl-xL inhibitor, gossypol and chemotherapeutic agents in non-Hodgkin's lymphoma cells. Cancer Biol Ther 2008; 7: 51-60.

115. Heist RS, Fain J, Chinnasami B, Khan W, Molina JR, Sequist LV et al. Phase I/II study of AT-101 with topotecan in relapsed and refractory small cell lung cancer. J Thorac Oncol 2010; 5: 1637-1643.

116. Liu G, Kelly WK, Wilding G, Leopold L, Brill K, Somer B. An open-label, multicenter, phase I/II study of single-agent AT-101 in men with castrate-resistant prostate cancer. Clin Cancer Res 2009; 15: 3172-3176.

117. Ready N, Karaseva NA, Orlov SV, Luft AV, Popovych O, Holmlund JT et al. Double-blind placebo-controlled, randomized phase 2 study of the proapoptotic agent AT-101 plus docetaxel, in second-line non-small cell lung cancer. J Thorac Oncol 2011; 6: 781-785.

118. Baggstrom MQ, Qi Y, Koczywas M, Argiris A, Johnson EA, Millward MJ et al. A phase study of AT-101 (Gossypol) in chemotherapy-sensitive recurrent extensive-stage small cell lung cancer. J Thorac Oncol 2011; 6: 1757-1760.

119. Sonpavde G, Matveev V, Burke JM, Caton JR, Fleming MT, Hutson TE et al. Randomized phase II trial of docetaxel plus prednisone in combination with placebo or AT-101, an ora small molecule Bcl-2 family antagonist, as first-line therapy for metastatic castrationresistant prostate cancer. Ann Oncol 2012; 23: 1803-1808.

120. Clinic MA. Phase $1 / / I$ Clinical Trial of Lenalidomide in Combination With AT-101 for the Treatment of Relapsed B-cell Chronic Lymphocytic Leukemia (B-CLL). ClinicalTrials.gov 2009

121. Shore GC, Viallet J. Modulating the bcl-2 family of apoptosis suppressors for potential therapeutic benefit in cancer. Hematology Am Soc Hematol Educ Program 2005; 2005 $226-230$.

122. Konopleva M, Watt J, Contractor R, Tsao T, Harris D, Estrov Z et al. Mechanisms of antileukemic activity of the novel Bcl-2 homology domain-3 mimetic GX15-070 (obatoclax). Cancer Res 2008; 68: 3413-3420.

123. Buet D, Gallais I, Lauret E, Denis N, Lombard B, Guillonneau F et al. Cotargeting signaling pathways driving survival and cell cycle circumvents resistance to Kit inhibitors in leukemia. Blood 2012; 119: 4228-4241.

124. Bonapace L, Bornhauser BC, Schmitz M, Cario G, Ziegler U, Niggli FK et al. Induction of autophagy-dependent necroptosis is required for childhood acute lymphoblastic leukemia cells to overcome glucocorticoid resistance. J Clin Invest 2010; 120: 1310-1323.

125. Campas C, Cosialls AM, Barragan M, Iglesias-Serret D, Santidrian AF, Coll-Mulet L et al. $\mathrm{Bcl}-2$ inhibitors induce apoptosis in chronic lymphocytic leukemia cells. Exp Hematol 2006; 34: 1663-1669

126. Trudel S, Li ZH, Rauw J, Tiedemann RE, Wen XY, Stewart AK. Preclinical studies of the pan-Bcl inhibitor obatoclax (GX015-070) in multiple myeloma. Blood 2007; 109 $5430-5438$.

127. Jona A, Khaskhely N, Buglio D, Shafer JA, Derenzini E, Bollard CM et al. The histone deacetylase inhibitor entinostat (SNDX-275) induces apoptosis in Hodgkin lymphoma cells and synergizes with Bcl-2 family inhibitors. Exp Hematol 2011; 39: 1007-1017 e1001.

128. O'Brien SM, Claxton DF, Crump M, Faderl S, Kipps T, Keating MJ et al. Phase I study of obatoclax mesylate (GX15-070), a small molecule pan-Bcl-2 family antagonist, in patients with advanced chronic lymphocytic leukemia. Blood 2009; 113: 299-305.
129. Schimmer AD, O'Brien S, Kantariian H, Brandwein J, Cheson BD, Minden MD et al. A phase I study of the pan bcl-2 family inhibitor obatoclax mesylate in patients with advanced hematologic malignancies. Clin Cancer Res 2008; 14: 8295-8301.

130. Hwang JJ, Kuruvilla J, Mendelson D, Pishvaian MJ, Deeken JF, Siu LL et al. Phase I dose finding studies of obatoclax (GX15-070), a small molecule pan-BCL-2 family antagonist, in patients with advanced solid tumors or lymphoma. Clin Cancer Res 2010; 16: $4038-4045$

131. Oki Y, Copeland A, Hagemeister F, Fayad LE, Fanale M, Romaguera J et al. Experience with obatoclax mesylate (GX15-070), a small molecule pan-Bcl-2 family antagonist in patients with relapsed or refractory classical Hodgkin lymphoma. Blood 2012; 119: 2171-2172.

132. Parikh SA, Kantarijan $H$, Schimmer A, Walsh W, Asatiani $E$, El-Shami $K$ et al. Phase II study of obatoclax mesylate (GX15-070), a small-molecule BCL-2 family antagonist, for patients with myelofibrosis. Clin Lymphoma Myeloma Leuk 2010; 10: 285-289.

133. Goard CA, Schimmer AD. An evidence-based review of obatoclax mesylate in the treatment of hematological malignancies. Core Evid 2013; 8: 15-26.

134. Stewart AK. Novel therapeutics in multiple myeloma. Hematology 2012; 17(Suppl 1): S105-S108.

135. Oltersdorf T, Elmore SW, Shoemaker AR, Armstrong RC, Augeri DJ, Belli BA et al. An inhibitor of Bcl-2 family proteins induces regression of solid tumours. Nature 2005; 435 : 677-681.

136. Brinkmann K, Hombach A, Michael Seeger J, Wagner-Stippich D, Klubertz D, Kronke M et al. SMAC mimetic potentiates tumor susceptibility towards natural killer cell-mediated killing. Leuk Lymphoma 2014; 55: 645-651.

137. Chauhan D, Velankar M, Brahmandam M, Hideshima T, Podar K, Richardson $\mathrm{P}$ et al. A novel $\mathrm{Bcl}-2 / \mathrm{Bcl}-\mathrm{X}(\mathrm{L}) / \mathrm{Bcl}-\mathrm{w}$ inhibitor $\mathrm{ABT}-737$ as therapy in multiple myeloma. Oncogene 2007; 26: 2374-2380.

138. Konopleva M, Contractor R, Tsao T, Samudio I, Ruvolo PP, Kitada S et al. Mechanisms of apoptosis sensitivity and resistance to the $\mathrm{BH} 3$ mimetic $\mathrm{ABT}-737$ in acute myeloid leukemia. Cancer Cell 2006; 10: 375-388.

139. Kuroda J, Puthalakath $\mathrm{H}$, Cragg MS, Kelly PN, Bouillet P, Huang DC et al. Bim and Bad mediate imatinib-induced killing of $\mathrm{Bcr} / \mathrm{Abl}+$ leukemic cells, and resistance due to their loss is overcome by a BH3 mimetic. Proc Natl Acad Sci USA 2006; 103 . 14907-14912.

140. Tse C, Shoemaker AR, Adickes J, Anderson MG, Chen J, Jin S et al. ABT-263: a potent and orally bioavailable Bcl-2 family inhibitor. Cancer Res 2008; 68: 3421-3428

141. Ackler S, Mitten MJ, Foster K, Oleksiiew A, Refici M, Tahir SK et al. The Bcl-2 inhibito ABT-263 enhances the response of multiple chemotherapeutic regimens in hematologic tumors in vivo. Cancer Chemother Pharmacol 2010; 66: 869-880.

142. Wilson WH, O'Connor OA, Czuczman MS, LaCasce AS, Gerecitano JF, Leonard JP et al. Navitoclax, a targeted high-affinity inhibitor of BCL-2, in lymphoid malignancies: a phase 1 dose-escalation study of safety, pharmacokinetics, pharmacodynamics, and antitumour activity. Lancet Oncol 2010; 11: 1149-1159.

143. Souers AJ, Leverson JD, Boghaert ER, Ackler SL, Catron ND, Chen J et al. ABT-199, a potent and selective BCL-2 inhibitor, achieves antitumor activity while sparing platelets. Nat Med 2013: 19: 202-208.

144. Vandenberg CJ, S Cory. ABT-199, a new Bcl-2-specific BH3 mimetic, has in vivo efficacy against aggressive Myc-driven mouse lymphomas without provoking thrombocytopenia. Blood 2013; 121: 2285-2288.

145. Touzeau C, Dousset C, Le Gouill S, Sampath D, Leverson JD, Souers AJ et al. The Bcl-2 specific BH3 mimetic ABT-199: a promising targeted therapy for $t(11 ; 14)$ multiple myeloma. Leukemia 2014; 28: 210-212.

146. Pan R, Hogdal LJ, Benito JM, Bucci D, Han L, Borthakur G et al. Selective BCL-2 inhibition by ABT-199 causes on target cell death in acute myeloid leukemia. Cancer Discov 2014; e-pub ahead of print 13 February 2014; doi:10.1158/2159-8290. CD-13-0609.

147. Khaw SL, Merino D, Anderson MA, Glaser SP, Bouillet $\mathrm{P}$, Roberts AW et al. Both leukaemic and normal peripheral $B$ lymphoid cells are highly sensitive to the selective pharmacological inhibition of pro-survival Bcl-2 with ABT-199. Leukemia 2014; e-pub ahead of print 9 January 2014; doi:10.1038/leu.2014.1

\footnotetext{
(c) (i) Cell Death and Disease is an open-access journal published by Nature Publishing Group. This work is licensed under a Creative Commons Attribution 3.0 Unported License. To view a copy of this license, visit http://creativecommons.org/ licenses/by/3.0/
} 